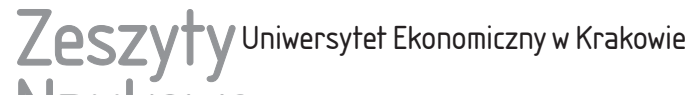 Naukowe
}

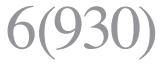

ISSN 1898-6447

Zesz. Nauk. UEK, 2014; 6(930): 101-116 DOI: 10.15678/ZNUEK.2014.0930.0607

\author{
Magdalena Gorzelany-Dziadkowiec \\ Ewa Kozień \\ Katedra Strategii Zarządzania i Rozwoju Organizacji \\ Uniwersytet Ekonomiczny w Krakowie
}

\section{Umocnienie pozycji konkurencyjnej małych i średnich przedsiębiorstw poprzez realizacje projektów}

\section{Streszczenie}

W artykule wyjaśniono istotę i determinanty konkurencyjności w rozwoju małych i średnich przedsiębiorstw. Podkreślono znaczenie zmian dynamizujących rozwój gospodarczy oparty na planie działań określonym w strategii lizbońskiej. Zwrócono uwagę na tworzenie warunków instytucjonalno-prawnych i finansowych, które wpływają na zwiększenie potencjału konkurencyjności małych i średnich firm w Polsce. Szczególnie skoncentrowano się na analizie wzrostu konkurencyjności firm przez realizację projektów. Badania zostały przeprowadzone w 30 małych i średnich firmach. W pierwszym etapie dokonano identyfikacji rodzajów projektów realizowanych w przedsiębiorstwach. $\mathrm{W}$ drugim etapie, na podstawie opracowanego arkusza oceny konkurencyjności projektów, przeprowadzono analizę korzyści w obszarze strategicznym, finansowym i społecznym wynikających z realizowanych przez firmy projektów. Projekty jako przedsięwzięcia unikatowe przyczyniają się do rozwoju małych i średnich firm oraz utrzymania ich pozycji konkurencyjnej.

Słowa kluczowe: rozwój, projekt, pozycja konkurencyjna, małe i średnie przedsiębiorstwa.

\section{Wprowadzenie}

Wyjście poza lokalne i krajowe uwarunkowania funkcjonowania małych i średnich przedsiębiorstw w Polsce skłoniło przedsiębiorców do poszukiwania nowych 
możliwości i sposobów ich rozwoju. Wymiar globalny i międzynarodowy dla sektora MSP jest wyzwaniem do podjęcia działań ekspansyjnych przyczyniających się do rozwoju i wzmocnienia pozycji konkurencyjnej. Konkurencyjność małych i średnich firm wynika z opanowania unikatowych umiejętności, które przyczyniają się do osiągnięcia sukcesu. Elementami budowania przewagi konkurencyjnej przedsiębiorstw są działania innowacyjne związane np. z wprowadzeniem lub modernizacją produkcji (usług), zabezpieczeniem jakości, doskonaleniem systemu zarządzania. Działania te mogą być realizowane jako projekty, którymi należy zarządzać. Konkurencyjność i projekty łączy cecha unikatowości, która pozwala firmie wyrosnąć ponad przeciętność.

Celem artykułu jest określenie wpływu realizowanych projektów na umocnienie pozycji konkurencyjnej małych i średnich przedsiębiorstw.

\section{Uwarunkowania konkurencyjności małych i średnich firm}

Globalizacja, nowe technologie i wymóg przejrzystości działalności gospodarczej spowodowały niepewność, która pojawiła się u większości osób zarządzających współcześnie przedsiębiorstwami. Niepewność, którą rodzi postępujący proces globalizacji, wywiera ogromny wpływ na formułowanie strategii rozwoju przedsiębiorstw. Rozwój współczesnych przedsiębiorstw związany jest ściśle z realizacją strategii opartej na konkurencyjności, a zysk nie jest już jedynym celem przedsiębiorstwa. Jak stwierdził P. Drucker, właściwym celem przedsiębiorstwa jest zadowolony klient, ponieważ to on zapewnia utrzymanie określonego udziału w rynku oraz osiągnięcie pozycji lidera, jak również zapewnia zyski, które potem mogą być reinwestowane w dalszy rozwój [Drucker i Kotler 2013, s. 43-44].

Strategia rozwoju oparta jest na konkurencyjności, dlatego warto w tym miejscu przybliżyć problematykę z nią związaną. Konkurencyjność jest definiowana przez wielu autorów w różny sposób. Przegląd jej definicji został zamieszczony w tabeli 1.

Tradycyjne podejścia do formułowania strategii mającej na celu uzyskanie przewagi konkurencyjnej często postrzegane są jako odpowiedź na zmiany i brak pewności. Większość formułowanych strategii ma na celu stworzenie trwałej przewagi konkurencyjnej dzięki pozycjonowaniu rynkowemu lub dzięki zapewnieniu zdolności i kompetencji niezbędnych, by tworzyć lub dostarczać produkty oraz usługi. Przedsiębiorstwa przeprowadzają przegląd strategii, wyznaczają kierunki działania i budują strukturę organizacyjną, biorąc za punkt wyjścia analizę sektora, w którym działają. Warto w tym miejscu zwrócić uwagę na fakt, że trwała przewaga konkurencyjna nie wynika z pozycjonowania, z właściwego wykorzystania zasobów, czy też analiz branży, lecz jej źródłem są cztery zdolności organizacyjne, które sprzyjają adaptacji [Reeves i Deimler 2012, s. 41]: 
- zdolność do odczytywania sygnałów nadchodzących zmian i podejmowania stosownych działań,

- zdolność do szybkiego i częstego eksperymentowania - nie tylko z produktami i usługami, ale również z modelami biznesowymi, procesami i strategiami,

- zdolność do zarządzania złożonymi i wzajemnie powiązanymi wielopodmiotowymi systemami,

- zdolność do motywowania pracowników i partnerów.

Tabela 1. Zestawienie definicji konkurencyjności według różnych autorów

\begin{tabular}{|c|c|c|}
\hline $\begin{array}{c}\text { G. Hamel } \\
\text { i C.K. Prahalad }\end{array}$ & D. Faulkner i C. Bowman & M. Gorynia \\
\hline $\begin{array}{l}\text { Konkurencyjność oznacza } \\
\text { osiąganie wysokiej jakości } \\
\text { produktów, które pozycjonują } \\
\text { organizację na pierwszym } \\
\text { miejscu wśród klientów } \\
\text { [Hamel i Prahalad 1993, s. } 75 \text { ] }\end{array}$ & $\begin{array}{l}\text { Konkurencyjność to posia- } \\
\text { danie przez przedsiębiorstwo } \\
\text { umiejętności osiągnięcia pozy- } \\
\text { cji lidera w branży [Faulkner } \\
\text { i Bowman 1996, s. 44] }\end{array}$ & $\begin{array}{l}\text { Konkurencyjność to umiejęt- } \\
\text { ność konkurowania, a więc } \\
\text { działania i przetrwania } \\
\text { w konkurencyjnym otoczeniu } \\
\text { [Gorynia 2002, s. 48] }\end{array}$ \\
\hline J. Burnewicz & M.J. Stankiewicz & W. Jakubik \\
\hline $\begin{array}{l}\text { Konkurencyjność to zdol- } \\
\text { ność do przeciwstawiania się } \\
\text { konkurencji [Burnewicz 1993, } \\
\text { s. 23] }\end{array}$ & $\begin{array}{l}\text { Konkurencyjność to zdolność } \\
\text { do sprawnego, czyli skutecz- } \\
\text { nego, korzystnego i ekono- } \\
\text { micznego osiągania celów na } \\
\text { rynkowej arenie konkuren- } \\
\text { cyjności [Stankiewicz 2002, } \\
\text { s. 36] }\end{array}$ & $\begin{array}{l}\text { Konkurencyjność jest to rela- } \\
\text { tywna zdolność do forsowania } \\
\text { własnego systemu celów, } \\
\text { zamierzeń bądź wartości } \\
\text { [Jakubik 2001, s. 3] }\end{array}$ \\
\hline
\end{tabular}

Źródło: opracowanie własne.

Globalizacja jest terminem stosunkowo młodym i związanym z powstaniem Unii Europejskiej. Onacza ona ujednolicenie gospodarek unijnych i łączenie się tamtejszych przedsiębiorstw w koncerny oraz korporacje. Globalizacja przejawia się głównie we wzroście współzależności rynków i produkcji w większości krajów świata przez handel towarami i usługami, międzynarodowe przepływy kapitału oraz technologii [Milewski 1999, s. 124-125]. Liberalizacja międzynarodowych przepływów towarów, usług i czynników wytwórczych wzmacnia konkurencję, a globalizacja otwiera nowe rynki, dzięki czemu zaostrza się walka konkurencyjna. Wpływ globalizacji na strategię konkurowania przedsiębiorstw przedstawiono w tabeli 2.

Obserwując zachodzący proces globalizacji, teoretycznie można wysunąć stwierdzenie, że dotyczy on głównie dużych przedsiębiorstw (korporacji), lecz w praktyce nie jest to prawda. Proces globalizacji wywołuje konieczność adaptacji i wprowadzania zmian w działalności wszystkich przedsiębiorstw, również małych i średnich. Przedsiębiorstwo, aby mogło konkurować na rynkach globalnych, musi 
brać pod uwagę nowe obszary, w których osiągać będzie swoje cele [Bieliński 2005, s. 15].

Tabela 2. Globalizacja a zmiany w strategiach konkurowania przedsiębiorstw

\begin{tabular}{|c|c|c|}
\hline Obszary konkurowania & $\begin{array}{c}\text { Priorytety w konkurencji } \\
\text { „tradycyjnej” }\end{array}$ & $\begin{array}{c}\text { Cele konkurowania } \\
\text { w nowej przestrzeni rynkowej }\end{array}$ \\
\hline Branża (sektor) & Konkurenci w sektorze & $\begin{array}{l}\text { Pojawienie się nowych i poten- } \\
\text { cjalnych sektorów }\end{array}$ \\
\hline Grupa strategiczna & $\begin{array}{l}\text { Nacisk na pozycję konkuren- } \\
\text { cyjną w grupie }\end{array}$ & $\begin{array}{l}\text { Inne grupy strategiczne } \\
\text { w obrębie branży }\end{array}$ \\
\hline Grupa docelowa & $\begin{array}{l}\text { Nacisk na poprawną obsługę } \\
\text { wybranego rynku docelowego } \\
\text { (segmentu) }\end{array}$ & $\begin{array}{l}\text { Tworzenie nowych grup } \\
\text { nabywców }\end{array}$ \\
\hline Produkty (oferty rynkowe) & $\begin{array}{l}\text { Maksymalizacja wartości } \\
\text { dodanej produktu w obrębie } \\
\text { branży }\end{array}$ & $\begin{array}{l}\text { Tworzenie wartości dodanej na } \\
\text { podstawie elementów wycho- } \\
\text { dzących poza branżę }\end{array}$ \\
\hline Czas & $\begin{array}{l}\text { Adaptacja do postrzeganych } \\
\text { trendów rozwoju branży }\end{array}$ & $\begin{array}{l}\text { Wpływ na kształt i charakter } \\
\text { trendów rozwoju w otoczeniu }\end{array}$ \\
\hline
\end{tabular}

Źródło: [Kalfas 2010, s. 471].

W związku z uwarunkowaniami, jakie tworzy globalizacja, polskie przedsiębiorstwa nie mogą być oceniane jedynie w skali krajowej na tle innych przedsiębiorstw w danym sektorze, ale konieczna jest ich ocena w skali międzynarodowej. Coraz większe znaczenie mają strategie konkurencji rozumiane jako kompleksowe, długofalowe koncepcje tworzenia względnie trwałej przewagi konkurencyjnej wobec wszystkich uczestników otoczenia. Jeżeli działania przedsiębiorstw są innowacyjne w skali świata, a firmy funkcjonują na rynku światowym, wówczas sektor uzyskuje przewagę konkurencyjną w układzie międzynarodowym.

Poprawie konkurencyjności w układzie międzynarodowym miała pomóc strategia lizbońska, która stanowi plan działań przyjęty przez przywódców krajów UE. Celem strategii było zdynamizowanie rozwoju gospodarczego w Unii Europejskiej, zapewnienie spójności społecznej oraz dbałość o zrównoważony rozwój i ekologię. Po kilku latach funkcjonowania strategii lizbońskiej dostrzeżono słabe efekty wdrażania jej celów co doprowadziło do odnowienia jej postanowień. W odniesieniu do Polski za najważniejsze działania prowadzące do pomyślnego spełnienia założeń odnowionej strategii uznano [Strategia Lizbońska i Europa 2020]:

- reformę sektora badań publicznych, która pozwoli zwiększyć wielkość inwestycji w wiedzę i innowacje oraz podniesie jakość B + R,

- stworzenie przyjaznego otoczenia instytucjonalno-legislacyjnego i finansowego dla dynamicznego rozwoju przedsiębiorczości oraz zwiększania potencjału konkurencyjności i generowania innowacji zwłaszcza przez MSP, 
- stworzenie nowoczesnego systemu transportowego i energetycznego, stanowiącego spójny element europejskich sieci infrastrukturalnych,

- modernizację systemów edukacji i kształcenia zawodowego, tak aby systemy te były zdolne do antycypacyjnej i elastycznej adaptacji do zmieniających się potrzeb i podaży na rynku pracy oraz aby przyczyniały się do zwiększania udziału osób dorosłych w kształceniu przez całe życie,

- reformę publicznych służb zatrudnienia, której efektem końcowym będzie wdrożenie efektywnych instrumentów aktywnej polityki rynku pracy, ukierunkowanych na bezrobotnych, szczególnie wśród młodzieży i osób starszych.

W zintegrowanej strategii centralne miejsce zajęła kwestia zwiększenia dynamiki przedsiębiorczości w Europie. Sektor MSP stanowi podporę gospodarki europejskiej i jest głównym źródłem miejsc pracy. Małe i średnie przedsiębiorstwa są bardzo wrażliwe na zmiany otoczenia gospodarczego, regulacyjnego i administracyjnego. Działania w strategii lizbońskiej zakładają podjęcie wysiłków mających na celu obniżenie kosztów prowadzenia działalności gospodarczej, wyeliminowanie zbędnej biurokracji, która poważnie utrudnia funkcjonowanie małych i średnich przedsiębiorstw. Promowane miały być przedsiębiorstwa rozpoczynające działalność gospodarczą na każdym etapie nauczania, zakładano wprowadzenie większej liczby zajęć, zwiększających przedsiębiorczość młodych osób, które wkrótce wkroczą na rynek pracy. W strategii postulowano również poprawę dostępu małych i średnich przedsiębiorstw do instrumentów finansowych, w szczególności do kapitału początkowego i mikropożyczek, zakładano również ułatwianie dostępu do technologii, promowanie idei innowacyjności i badań oraz reformę systemu edukacji [Strategia Lizbońska - droga...].

Rzeczywistość wykazuje, że małe i średnie przedsiębiorstwa napotykają jednak pewne ograniczenia nie tylko wewnętrzne, ale także zewnętrzne. Podstawowym ograniczeniem konkurencyjności MSP jest trudny dostęp do środków finansowych z instytucji finansowych. Często taki stan rzeczy powodują wysokie stopy procentowe kredytów, wymagania formalne do uzyskania środków (np. zabezpieczenia). Brak środków finansowych skutkuje niewielkimi możliwościami rozwojowymi przedsiębiorstwa. Kapitał finansowy często pochodzi z własnych oszczędności, pożyczek od rodziny czy znajomych.

Drugą determinantą osłabiającą konkurencyjność MSP jest wysoce scentralizowany i często patriarchalny sposób kierowania przedsiębiorstwem, który ogranicza w bardzo dużym stopniu stosowanie odpowiednich technik zarządzania. Również w małych i średnich przedsiębiorstwach występują ograniczenia strukturalne. Pomimo że struktury organizacyjne nadają omawianym przedsiębiorstwom dynamizm i są proinnowacyjne, to często mogą być ich słabością (np. nadmierna centralizacja władzy, brak jasno określonych zakresów zadań). Kwestię tę można 
rozwiązać przez podniesienie kwalifikacji kadry kierowniczej i zwiększenie decentralizacji władzy.

Bardzo częstym problemem utrudniającym funkcjonowanie MSP jest brak planów działalności, w tym długo- i średnioterminowych. Powodem tego jest przeświadczenie o braku korzyści z ustalenia celów i sposobu ich osiągania oraz niekiedy brak wiedzy z zakresu planowania. Ograniczone zasoby finansowe powodują, że małe i średnie przedsiębiorstwa nie korzystają z zewnętrznych źródeł wiedzy naukowej lub technologicznej oraz usług świadczonych przez instytucje doradcze.

Niewielki wpływ na rynek oraz brak orientacji marketingowej osłabiają konkurencyjność sektora MSP. Atutem, ale zarazem słabością omawianych przedsiębiorstw może być brak silnej identyfikacji rynkowej. Małe i średnie przedsiębiorstwa są mniej zauważalne na rynku, dlatego mogą częściej zmieniać strategię działania, podejmować eksperymenty, nie obawiając się utraty znacznej pozycji rynkowej czy cech marki. Natomiast zanik orientacji marketingowej jest wynikiem braku wyspecjalizowanych komórek, które profesjonalnie zajęłyby się tą stroną działalności przedsiębiorstwa [Kształtowanie konkurencyjności... 2011].

Podsumowując tę część rozważań, stwierdzić należy, że małe i średnie przedsiębiorstwa powinny posiadać świadomość konieczności wzmacniania pozycji konkurencyjnej na rynkach międzynarodowych. Postępująca globalizacja wymaga, aby przedsiębiorstwa wprowadzały zmiany, były elastyczne i innowacyjne. W założeniach strategii lizbońskiej małym i średnim przedsiębiorstwom poświęcono dużo uwagi, gdyż to właśnie sektor MSP determinuje wzrost gospodarczy. Niemniej sektor ten napotyka wiele barier w zwiększaniu swojej konkurencyjności. W związku z powyższym małe i średnie przedsiębiorstwa, budując przewagę konkurencyjną, powinny wzmacniać swoją pozycję za pomocą czynników zarówno wewnętrznych, jak i zewnętrznych. Jedną z możliwości w tym zakresie jest wykorzystywanie projektów.

\section{Znaczenie koncepcji zarządzania projektami w rozwoju małych i średnich firm}

Zmiany i rosnąca konkurencja w wymiarze lokalnym, międzynarodowym i globalnym wpływa na zmianę postaw i zachowań przedsiębiorców małych i średnich firm, którzy poszukują skutecznych możliwości rozwoju i utrzymania pozycji konkurencyjnej. Taką drogą może być rozwój firm poprzez realizację różnorodnych projektów oraz przekształcanie organizacji tradycyjnej w organizację projektową, która cechuje się: 
- podejściem holistycznym (całościowym) do wykonywanych projektów,

- stosowaniem metod, technik i metodyk zarządzania projektami,

- standaryzacją procedur i dokumentów,

- ciągłym doskonaleniem procesów (robieniem rzeczy we właściwy sposób oraz robieniem właściwych rzeczy),

- gromadzeniem i upowszechnianiem baz wiedzy projektowej przez tworzenie biur zarządzania projektami,

- korzystaniem z zaawansowanej wiedzy interdyscyplinarnej,

- wykorzystywaniem doświadczenia projektowego w celu tworzenia „nowej wiedzy",

- zarządzaniem zmianami organizacyjnymi,

- tworzeniem kultury projektowej,

- zastosowaniem systemów informatycznych w zarządzaniu projektami.

Organizacja projektowa funkcjonuje według odmiennych zasad, które zapewniają efektywność wykonania kolejnych projektów. Zmiany w systemie zarządzania projektami tkwią w istocie samego projektu. Działania projektowe różnią się od rutynowych, ich specyfikę wyjaśniają cechy projektu.

Projekt w literaturze przedmiotu najczęściej definiowany jest jako przedsięwzięcie o charakterze unikatowym i tymczasowym, które charakteryzuje się następującymi cechami [PMBoK 2008, s. 9]:

- unikatowością i niepowtarzalnością rozwiązania zarówno w fazie koncepcji, jak i realizacji oraz wdrożenia,

- celami projektu, które są specyficzne i wyrażone przez parametry: kosztu, czasu i jakości,

- realizacją i wdrożeniem projektu, który powinien stanowić korzystną zmianę, wyrażoną poprzez ilościowe i jakościowe mierniki,

- realizacją projektu, który nie jest powiązany z bieżącymi zadaniami przedsiębiorstwa,

- realizacją projektu, który uwzględnia ograniczenia zasobów przedsiębiorstwa,

- tym, że jest zróżnicowany pod względem złożoności, zakresu oraz wykorzystania specyficznych zasobów.

Wyróżnione podstawowe cechy projektów odnoszą się do wszystkich rodzajów projektów realizowanych przez przedsiębiorstwa. Z uwagi na różnorodność projektów można je klasyfikować według wielu kryteriów. W tabeli 3 zestawiono rodzaje projektów ze względu na wybrane kryteria.

Elementem łączącym konkurencyjność i projekty jest unikatowość. Unikatowość rozwiązań projektowych w praktyce ma związek z unikatowością umiejętności opanowanych przez przedsiębiorstwa. Unikatowość umożliwia 
współczesnym firmom wybicie się ponad przeciętność w wymiarze lokalnej lub międzynarodowej działalności, a także przyczynia się do ich rozwoju.

Tabela 3. Klasyfikacja projektów

\begin{tabular}{|l|l|}
\hline \multicolumn{1}{|c|}{ Kryterium klasyfikacji } & \multicolumn{1}{c|}{ Rodzaje projektów } \\
\hline Zasięg geograficzny & $\begin{array}{l}\text { lokalne } \\
\text { krajowe } \\
\text { międzynarodowe } \\
\text { globalne }\end{array}$ \\
\hline Rozmiar & $\begin{array}{l}\text { małe } \\
\text { duże }\end{array}$ \\
\hline Orientacja & $\begin{array}{l}\text { zorientowane procesowo } \\
\text { zorientowane obiektowo }\end{array}$ \\
\hline Finansowanie & $\begin{array}{l}\text { zewnętrzne } \\
\text { wewnętrzne }\end{array}$ \\
\hline Stopień nowatorskości & $\begin{array}{l}\text { wysoki stopień nowości } \\
\text { niski stopień nowości }\end{array}$ \\
\hline Powiązanie z obszarem działalności & $\begin{array}{l}\text { inwestycyjne } \\
\text { produkcyjne } \\
\text { techniczne } \\
\text { zarządcze } \\
\text { marketingowe } \\
\text { informatyczne itp. }\end{array}$ \\
\hline
\end{tabular}

Źródło: [Łada i Kozarkiewicz 2010, s. 12].

Projekt w wymiarze konkurencyjności można interpretować jako korzystną zmianę mającą na celu poprawę efektywności działania przedsiębiorstwa oraz jako wartość ekonomiczną, techniczną i społeczną.

Wartość projektu wiąże się ze stopniem osiągania zamierzonego celu, który jest określony przez następujące parametry:

- zakres projektu,

- czas realizacji,

- koszty realizacji,

- jakość.

Wymienione podstawowe parametry są ze sobą ściśle powiązane, co oznacza, że są one krytyczne, jeżeli chodzi o zarządzanie projektem oraz osiągnięcie sukcesu przez organizację. Wartościując zakres, jakość, czas i koszt projektu ze względu na optymalizację celu, menedżerowie dążą do doskonalenia jakości, precyzyjnego zdefiniowania zakresu ze względu na klienta oraz optymalizacji czasu i kosztów. Wartość projektu jest sumą korzyści strategicznych, ekonomicznych i społecznych, przyczyniających się do rozwoju organizacji i społeczeństwa. 
Korzyści strategiczne wynikające z realizowanych projektów związane są z rozwojem rynku, satysfakcją klientów i rozwojem organizacji. Ważne są korzyści ekonomiczne, związane ze zwrotem nakładów poniesionych na wykonanie i wdrożenie projektu. Korzyści ekonomiczne generują zysk, który decyduje o rozwoju przedsiębiorstwa w przyszłości i o możliwości realizowania innowacyjnych projektów. Korzyści społeczne z jednej strony związane są z pogłębianiem przez menedżerów wiedzy, kompetencji i umiejętności dotyczących zarządzania projektami oraz zdobyciem nowych doświadczeń z zakresu realizacji danego typu projektów (kapitał intelektualny). Z drugiej strony szeroko pojęte korzyści społeczne wynikają z rozwoju wszystkich obszarów dotyczących funkcjonowania społeczeństwa. Korzyści z wykonania projektów można rozpatrywać w kategorii korzyści materialnych i niematerialnych, które mają charakter komplementarny.

Popularnym obecnie podejściem do zarządzania projektami w sytuacji nieprzewidywalności otoczenia i wciąż wzrastającej konkurencji, obok tradycyjnego, jest podejście adaptacyjne.

Podejście tradycyjne do zarządzania projektem sprawdza się w sytuacji, gdy można wykorzystać wiedzę i doświadczenie nabyte w realizacji podobnych projektów. Parametry i czynniki projektu cechują się w tym podejściu niskim stopniem niepewności. Istnieją też duże szanse rozwoju projektu zgodnie z oczekiwaniami.

Z kolei podejście adaptacyjne w zarządzaniu projektem jest przydatne, gdy mamy do czynienia $\mathrm{z}$ trudno przewidywalnymi zagrożeniami, parametry i czynniki projektu cechują się wysokim stopniem niepewności, a ryzyko jest trudno przewidywalne. Uczestnicy projektu uczą się w trakcie realizacji projektu, dokonują odkryć, napotykają nieoczekiwane problemy. Podejście adaptacyjne wykorzystywane jest do projektów o wysokim stopniu nowości. Zorientowane jest ono na ciągły rozwój produktów, technologii oraz narzędzi informatycznych. Adaptacyjność w zarządzaniu projektem jest miarą jego sukcesu.

\section{Cel, zakres i metodyka badań}

Metodyka badawcza przyjęta w niniejszej pracy obejmowała następujące etapy:

1) określenie celu i przedmiotu badania,

2) opracowanie i zastosowanie metody badawczej,

3) zebranie informacji,

4) identyfikację rodzajów projektu,

5) ocenę wpływu realizowanych projektów na konkurencyjność małych i średnich firm. 
Celem badania była ocena wpływu realizowanych projektów przez małe i średnie firmy na umocnienie ich pozycji konkurencyjnej. Cele szczegółowe dotyczyły identyfikacji typów projektów oraz określenia wpływu rodzaju projektów na budowanie konkurencyjności małych i średnich firm w wymiarze strategicznym, finansowym i społecznym. Ponadto przyjęto do badania założenie, że ocenie podlegają projekty wyłącznie wdrożone.

Badaniem objęto 30 małych i średnich firm, w tym 6 średnich i 24 małych (11 spośród małych firm to firmy rodzinne). Przedmiot działalności badanych firm był zróżnicowany i obejmował działalność związaną z handlem, budownictwem, informatyką, stomatologią, cukiernictwem, gastronomią, działalnością produkcyjną i usługami.

W celu określenia wpływu realizowanych projektów na konkurencyjność małych i średnich firm opracowano arkusz diagnostyczny, który składał się z metryczki dotyczącej informacji o firmie (o jej wielkości, czasie funkcjonowania, przedmiocie działania) oraz z części badawczej. Część diagnostyczna zawierała listę różnych rodzajów projektów oraz stopień oceny ich wpływu na budowanie konkurencyjności w wymiarze strategicznym, finansowym i społecznym.

Informacje do badania uzyskano na podstawie wywiadu standaryzowanego przeprowadzonego $\mathrm{z}$ właścicielami, menedżerami i pracownikami firm oraz opracowanego kwestionariusza diagnostycznego.

W badanych firmach przedsiębiorcy realizowali następujące projekty:

- produkcyjno-techniczne związane z wprowadzeniem nowego produktu lub modernizacją dotychczasowego,

- architektoniczne,

- inwestycyjne,

- marketingowe,

- informatyczne, związane z projektowaniem i zastosowaniem programów informatycznych do realizacji funkcji zarządzania, tj. finansowej, personalnej, gospodarki magazynowej, jak również do dywersyfikacji tradycyjnej formy handlu poprzez uruchomienie sklepu internetowego,

- kooperacyjne.

W tabeli 4 zestawiono projekty, które zostały zrealizowane w badanych firmach. Analiza korzyści wynikających z przeprowadzanych projektów dotyczyła wymiaru strategicznego, finansowego oraz społecznego. Ocena została dokonana w skali trójstopniowej przez przedsiębiorców w zakresie efektów mierzalnych (finansowych), niemierzalnych (np. doskonalących proces zarządzania firmą). Oceniono, czy realizowany projekt miał zdecydowany (Z), czy częściowy (C) wpływ na rozwój firmy i umocnienie jej pozycji konkurencyjnej, czy też widoczny był brak wpływu (B). 
Tabela 4. Lista oceny konkurencyjności realizowanych projektów w badanych małych i średnich firmach w obszarze strategicznym, finansowym i społecznym

\begin{tabular}{|c|c|c|c|c|c|c|c|c|c|}
\hline \multirow{3}{*}{ Typy projektów } & \multicolumn{9}{|c|}{ Korzyści } \\
\hline & \multicolumn{3}{|c|}{$\begin{array}{l}\text { strategiczne } \\
\text { (poszerzenie } \\
\text { rynków) }\end{array}$} & \multicolumn{3}{|c|}{ finansowe } & \multicolumn{3}{|c|}{ społeczne } \\
\hline & $\mathrm{Z}$ & $\mathrm{C}$ & B & $\mathrm{Z}$ & $\mathrm{C}$ & B & $\mathrm{Z}$ & $\mathrm{C}$ & B \\
\hline $\begin{array}{l}\text { Projekty produkcyjne: } \\
\text { - nowe produkty }(3)\end{array}$ & + & $\begin{array}{l}+ \\
+\end{array}$ & & $\begin{array}{l}+ \\
+\end{array}$ & + & & $\begin{array}{l}+ \\
+\end{array}$ & + & \\
\hline $\begin{array}{l}\text { - udoskonalanie dotychczasowych produktów, } \\
\text { ich modernizacja (6) }\end{array}$ & $\begin{array}{l}+ \\
+ \\
+ \\
+ \\
+\end{array}$ & + & & $\begin{array}{l}+ \\
+\end{array}$ & $\begin{array}{l}+ \\
+ \\
+ \\
+\end{array}$ & & $\begin{array}{l}+ \\
+ \\
+ \\
+ \\
+ \\
+\end{array}$ & & \\
\hline - nowa technologia produkcji (2) & $\begin{array}{l}+ \\
+\end{array}$ & & & & $\begin{array}{l}+ \\
+\end{array}$ & & $\begin{array}{l}+ \\
+\end{array}$ & & \\
\hline $\begin{array}{l}\text { - modernizacja dotychczasowej technologii } \\
\text { produkcji (3) }\end{array}$ & + & $\begin{array}{l}+ \\
+\end{array}$ & & & $\begin{array}{l}+ \\
+ \\
+\end{array}$ & & $\begin{array}{l}+ \\
+\end{array}$ & + & \\
\hline - wdrożenie projektu zarządzania jakością (2) & & $\begin{array}{l}+ \\
+\end{array}$ & & & $\begin{array}{l}+ \\
+\end{array}$ & & $\begin{array}{l}+ \\
+\end{array}$ & & \\
\hline $\begin{array}{l}\text { Projekty inwestycyjne: } \\
\text { - budowa nowych obiektów (3) }\end{array}$ & & $\begin{array}{l}+ \\
+ \\
+\end{array}$ & & & $\begin{array}{l}+ \\
+ \\
+\end{array}$ & & + & $\begin{array}{l}+ \\
+\end{array}$ & \\
\hline $\begin{array}{l}\text { Projekty finansowe: } \\
\text { - pozyskanie kapitału z instytucji okołobizne- } \\
\text { sowych (3) }\end{array}$ & & & $\begin{array}{l}+ \\
+ \\
+\end{array}$ & & & $\begin{array}{l}+ \\
+ \\
+\end{array}$ & & & $\begin{array}{l}+ \\
+ \\
+\end{array}$ \\
\hline - wejście na giełdę (2) & & $\begin{array}{l}+ \\
+\end{array}$ & & & $\begin{array}{l}+ \\
+\end{array}$ & & & $\begin{array}{l}+ \\
+\end{array}$ & \\
\hline $\begin{array}{l}\text { Projekty marketingowe i reklamowe: } \\
\text { - opracowanie i wdrożenie strategii marketin- } \\
\text { gowej (3) }\end{array}$ & & $\begin{array}{l}+ \\
+ \\
+\end{array}$ & & + & $\begin{array}{l}+ \\
+\end{array}$ & & & $\begin{array}{l}+ \\
+ \\
+\end{array}$ & \\
\hline - wybór i opracowanie formy reklamy (1) & + & & & + & & & & + & \\
\hline $\begin{array}{l}\text { Projekty informatyczne: } \\
\text { - dotyczące zarządzania funkcją (5): } \\
\text { finansową, } \\
\text { kadrową, } \\
\text { gospodarką materiałową }\end{array}$ & $\begin{array}{l}+ \\
+ \\
+ \\
+ \\
+\end{array}$ & & & & $\begin{array}{l}+ \\
+ \\
+ \\
+ \\
+\end{array}$ & & & $\begin{array}{l}+ \\
+ \\
+ \\
+ \\
+\end{array}$ & \\
\hline - dotyczące sklepu internetowego (1) & + & & & & + & & + & & \\
\hline
\end{tabular}


cd. tabeli 4

\begin{tabular}{|c|c|c|c|c|}
\hline \multirow[b]{2}{*}{ Typy projektów } & \multicolumn{4}{|c|}{ Korzyści } \\
\hline & $\begin{array}{c}\text { strategiczne } \\
\text { (poszerzenie } \\
\text { rynków) }\end{array}$ & finansow & & ołeczne \\
\hline $\begin{array}{l}\text { Projekty kooperacyjne (1): } \\
\text { - nawiązanie ścisłej współpracy z innymi fir- } \\
\text { mami w zakresie technologii, handlu, doradz- } \\
\text { twa itp. }\end{array}$ & + & + & + & \\
\hline
\end{tabular}

Źródło: opracowanie własne.

Łącznie w badanych 30 małych i średnich firmach wdrożono 34 projekty, co oznacza, że w czterech firmach jednocześnie realizowano po dwa projekty. Ta sytuacja dotyczyła średniej wielkości firm, w których obok projektów modernizacyjnych realizowano projekty informatyczne z zakresu zarządzania wybranymi funkcjami przedsiębiorstwa.

Projekty zrealizowane w badanych firmach charakteryzowały się lokalnym lub krajowym zasięgiem. Większość stanowiły małe projekty o niskim stopniu nowości, dużych projektów było jedynie pięć, a dwa z nich cechowały się wyższym stopniem nowości. Projekty były zorientowane procesowo i obiektowo.

Małe firmy koncentrowały się na wdrażaniu jednego projektu związanego z przedmiotem działalności firmy, co jest uwarunkowane ograniczeniem zasobów finansowych. Ta prawidłowość wiąże się z orientacją skierowaną na rozwój produktu lub usługi. Projekty dotyczące usprawniania zarządzania są realizowane dopiero w fazie wzrostu lub dojrzałości.

W wyniku przeprowadzonych badań można stwierdzić, że w części przebadanych małych firm są wdrażane modernizacyjne rozwiązania, które przez przedsiębiorców nie są określane jako projekty, choć intuicyjnie mają oni świadomość, że podejmowane działania mogą umocnić pozycję konkurencyjną firmy.

Na wdrożenie nowych projektów produkcyjnych ma wpływ kreatywność, wiedza i umiejętności przedsiębiorców oraz pracowników firmy. Opracowane nowe, innowacyjne produkty w praktyce są również motywem powstawania firm. Analizie poddano trzy projekty wdrożenia nowego produktu, przy czym dwa z nich zostały wykonane w firmach średniej wielkości. Jeden z projektów skłonił pomysłodawcę do założenia firmy, choć jak sam stwierdził - nigdy o tym nie myślał. Wdrożenie nowych produktów zdecydowanie ma wpływ na poprawę pozycji konkurencyjnej firmy, zwłaszcza gdy są to produkty zaspokajające potrzeby klientów. Nowe produkty otwierają możliwości rozszerzenia rynku, lecz w przypadku małych firm potencjał produkcyjny może okazać się niewystarczający, by mogły one sprostać zapotrzebowaniu. Tworzenie nowych produktów 
w małych firmach bywa działaniem o charakterze nieplanowanym. Podczas produkcji rodzi się nowy pomysł, tworzona jest nowa receptura (np. w cukierniach). Powstałe ad hoc nowe produkty są weryfikowane przez klientów.

Projekty dotyczące zastosowania nowej i modernizacji dotychczasowej technologii związane są z możliwościami finansowymi przedsiębiorstw. Jeden z nich polegał na kompleksowej zmianie technologii produkcji, co umożliwiło równocześnie wprowadzenie nowych produktów oraz udoskonalenie dotychczasowych. Projekt ten był poprzedzony projektem inwestycyjnym, zwiększającym powierzchnię produkcyjną. Projekty modernizacyjne są częściej realizowane w firmach i mają charakter połowicznych rozwiązań.

Wdrożone projekty zarządzania jakością dotyczyły procesów technologicznych (product quality assurance) oraz procesów zarządzania (project quality assurance). Zabezpieczenie jakości zorientowane jest na korzyści oraz wartości optymalnych wymagań stawianych firmie przez klienta. Motywem do wdrażania projektów zarządzania jakością jest możliwość podjęcia współpracy z kooperantami na rynku krajowym i międzynarodowym. Jedna z firm nawiązała ścisłą współpracę z firmami zagranicznymi w zakresie dostarczania produktów do wykonywanych usług remontowych. Ponadto pracownicy uczestniczyli w szkoleniach organizowanych przez firmy kooperujące, które zakończone były certyfikacją ich umiejętności i gwarancją jakości wykonanych prac. Zgodnie z wymogami unijnymi w cukierni wdrożono projekt HACCP, związany z zapewnieniem jakości żywności.

Projekty inwestycyjne są realizowane, gdy przedsiębiorcy świadomie podejmują decyzję o rozwoju firmy poprzez budowę nowych obiektów (filii). Projekty marketingowe i reklamowe w przypadku badanych firm realizowane były przez pracowników firm i cechowały się oszczędnością ponoszonych na nie nakładów. Jeżeli chodzi o projekty informatyczne, są one powszechnie wykorzystywane w zarządzaniu firmą. Wszystkie badane firmy posiadają stronę internetową i korzystają z informatycznych programów stosowanych do zarządzania podstawowymi funkcjami. W jednej z firm zlecono wykonanie specjalistycznego programu informatycznego, który usprawnił zarządzanie gospodarką materiałową, umożliwił na bieżąco śledzenie przez przedsiębiorcę stopnia zaawansowania robót (kilku równocześnie) oraz wykorzystanie zaprojektowanego algorytmu do określenia kosztów wykonywanych prac. W firmie handlowej zrealizowano projekt sklepu internetowego, który był uzupełnieniem tradycyjnego handlu.

$\mathrm{Z}$ badanych firm tylko jedna ściśle współpracowała z dostawcami produktów oraz w zakresie szkoleń pracowników. Pozostałe nie podjęły ścisłej współpracy $\mathrm{z}$ innym przedsiębiorstwem.

Projekty realizowano w firmach według tradycyjnego podejścia do zarządzania projektami, wykorzystując podstawowe rozwiązania systemowe i meto- 
dyczne. Jedynie realizacja projektów informatycznych była oparta na metodykach zwinnych, charakterystycznych dla podejścia adaptacyjnego.

Reasumując, projekty z jednej strony są przedsięwzięciami świadomie planowanymi i wdrażanymi przez przedsiębiorców, a z drugiej - są odpowiedzią na zmiany pojawiające się w otoczeniu (np. postęp techniczny). Z uwagi na ograniczone zasoby, w małych i średnich firmach nie jest możliwe realizowanie portfela projektów. Projekty modernizacyjne są częściej podejmowane przez małe i średnie firmy. Mają one na celu poprawę parametrów, które przyczyniają się do zwiększenia walorów użytkowych i czynią produkt (usługę) wartościowym.

Przedsiębiorcy badanych firm stwierdzili, że realizacja projektów wpływa na wzrost konkurencyjności w obszarze strategicznym, finansowym i społecznym, choć stopień wpływu projektów jest zróżnicowany. W największym zakresie oddziaływanie projektów dotyczy obszaru społecznego i strategicznego, a najbardziej zróżnicowane jest w obszarze finansowym. Przedsiębiorcy narzekali na trudności w pozyskaniu finansowania zewnętrznego z instytucji otoczenia biznesowego na realizowane projekty. Zdecydowanie stwierdzili, że projekty finansowane są ze środków własnych.

W firmach rozwijających się przez projekty można zauważyć sposób realizacji projektów równoległy bądź szeregowy (zjawisko ciągu projektowego polegające na realizacji sekwencji zależnych od siebie projektów, np. projekt inwestycyjny poprzedza projekt techniczno-produkcyjny).

Badane małe i średnie firmy nie tworzą organizacji o charakterze projektowym, choć występują pojedyncze jej cechy. W dwóch firmach działają biura wsparcia projektów, lecz ich rola sprowadza się jedynie do archiwizacji dokumentów wykonanych projektów, a nie gromadzenia wiedzy i doświadczenia. Zauważalna jest orientacja na współpracę i tworzenie zespołów projektowych oraz wykorzystywanie podstawowych metod zarządzania projektem. W badanych firmach nie stosowano typowych elastycznych rozwiązań strukturalnych, tj. struktur macierzowych, projektowych czy sieciowych.

\section{Podsumowanie}

Zasięg i intensywność zmian otoczenia w wymiarze politycznym, ekonomicznym i społecznym skłania przedsiębiorstwa do poszukiwania skutecznych dróg rozwoju. Wzrost konkurencji lokalnej, krajowej i międzynarodowej pobudza przedsiębiorców do twórczej aktywności, która decyduje o sukcesie przedsiębiorstwa. Konkurencyjność jest kluczowym zachowaniem stymulującym małe i średnie firmy do działania, jest ona dla nich impulsem sprawnego osiągania celów poprzez projekty. Projekty umożliwiają małym i średnim firmom budo- 
wanie trwałej przewagi konkurencyjnej w obszarze kosztowym, innowacyjnym i jakościowym. Sektor małych i średnich firm ma kluczowe znaczenie dla rozwoju gospodarczego kraju, dlatego należy wzmocnić wsparcie instytucji otoczenia biznesu oraz stworzyć ściślejsze powiązanie nauki z biznesem w celu zwiększenia innowacyjności realizowanych przez nie projektów.

\section{Literatura}

Bieliński J. [2005], Konkurencyjność przedsiębiorstw w świetle Strategii Lizbońskiej, CeDeWu, Warszawa.

Burnewicz J. [1993], Ekonomika transportu, Uniwersytet Gdański, Gdańsk.

Drucker P., Kotler P. [2013], Kim są nasi klienci? [w:] P. Drucker, Pięć najważniejszych pytań, Wolters Kluwer, Warszawa.

Faulkner D., Bowman C. [1996], Strategie konkurencji, Gebethner, Warszawa.

Gorynia M. [2002], Luka konkurencyjna na poziomie przedsiębiorstwa a przystapienie Polski do Unii Europejskiej, Akademia Ekonomiczna w Poznaniu, Poznań.

Hamel G., Prahalad C.K. [1993], Strategy as Stretch and Leverage, „Harvard Business Review", nr 4.

Jakubik W. [2001], Konkurencyjność gospodarki polskiej. Stan i perspektywy, Materiały z VII Kongresu Ekonomistów Polskich, styczeń, sesja IV, z. 7.

Kalfas E. [2010], Konkurencyjność przedsiębiorstw w świetle Strategii Lizbońskiej, V Krakowska Konferencja Młodych Uczonych, Kraków.

Kształtowanie konkurencyjności i przewagi konkurencyjnej małych i średnich przedsiębiorstw [2011], red. A. Adamik, Wydawnictwo C.H. Beck, Warszawa.

Łada M., Kozarkiewicz A. [2010], Zarzadzanie wartościa projektów. Instrumenty rachunkowości zarzadczej i controllingu, Wydawnictwo C.H. Beck, Warszawa.

Milewski R. [1999], Podstawy ekonomii rynkowej, PWN, Warszawa.

PMBoK [2008], A Guide to the Project Management. Body of Knowledge, Project Management Institute Standard Committee, Upper Derby.

Reeves M., Deimler M. [2012], Zdolność do adaptacji źródłem nowej przewagi konkurencyjnej, „Harvard Business Review Polska”, grudzień 2011-styczeń.

Stankiewicz M.J. [2002], Konkurencyjność przedsiębiorstwa. Budowanie konkurencyjności w warunkach globalizacji, TNOiK, Torun.

Strategia Lizbońska - droga do sukcesu zjednoczonej Europy, Departament Analiz Ekonomicznych i Społecznych, Urząd Komitetu Integracji Europejskiej.

Strategia Lizbońska i Europa 2020, http://www.mojregion.eu/regionalny-program-operacyjny (data dostępu: 13.01.2014).

\section{Strengthening the Competitive Position of Small and Medium Enterprises through Project Realisation}

The article explains the essence and determinants of competitiveness in the development of small and medium enterprises. It emphasises the importance of changes which accelerate economic growth based on the plan of action laid out in the Lisbon 
Strategy. It focuses on creating the legal-institutional and finance circumstances influencing the competitiveness potential of small and medium enterprises in Poland. Particular attention is devoted to how project realisation strengthens the competitive position of small and medium enterprises. Research was carried out at 30 small and medium enterprises. The first stage identified the types of projects realised. Based on a defined scoreboard of project competitiveness, the second analysed advantages gained in the fields of strategy, finance and social life thanks to projects realised by firms. The projects, as unique measures, contribute to the growth of small and medium firms and help them maintain their competitive position.

Keywords: development, project, competitive position, small and medium enterprises. 